\title{
PENGARUH PENAMBAHAN AEROSIL TERHADAP SIFAT FISIK SUPPOSITORIA EKSTRAK DAUN BAYAM DURI (Amaranthus Spinosus, Linn) DENGAN BASIS BERLEMAK (Oleum Cacao)
}

\author{
Evi Mulyani \\ Dosen Program studi D III Farmasi, Fakultas IImu Kesehatan, \\ Universitas Muhammadiyah Palangkaraya \\ e-mail: evi.muly4ni@gmail.com
}

\begin{abstract}
ABSTRAK
Bayam duri (Amaranthus spinosus Linn) merupakan tanaman dengan kandungan kuersetin yang digunakan masyarakat Indonesia sebagai obat wasir dengan cara direbus, kemudian air rebusan digunakan untuk mencuci dan mengompres bagian anus. Penggunaan dengan cara tersebut tidak efisien dan tidak efektif, sehingga harus diformulasikan dalam sediaan yang cocok yaitu suppositoria dengan basis berlemak (Oleum cacao). Karena oleum cacao mempunyai viskositas rendah dan sukar bercampur dengan ekstrak maka perlu ditambahkan aerosil, dimana aerosil merupakan zat tambahan yang digunakan sebagai pendispersi dan mampu meningkatkan viskositas. Sehingga penelitian ini bertujuan untuk mengetahui bagaimana pengaruh penambahan aerosil terhadap sifat fisik sediaan suppositoria ekstrak daun bayam duri dengan basis berlemak (oleum cacao). Ekstrak daun bayam duri dibuat menggunakan metode soxhletasi dengan pelarut etanol dan di lakukan penguapan dengan rotary evaporator sehingga diperoleh ekstrak kental, kemudian di identifikasi kandungan zat aktifnya (kuersetin) dengan metode KLT densitometri. Pembuatan suppositoria ekstrak daun bayam duri menggunakan metode peleburan dengan penambahan aerosil 1\% (FI), 2\% (FII), dan 3\% (FIII). Suppositoria yang dihasilkan kemudian diuji sifat fisiknya seperti keseragaman bobot, kekerasan, suhu leleh, dan waktu leleh. Data kemudian di analisis secara teoritis dengan membandingkan hasil uji dengan persyaratan yang sudah ditentukan dalam literatur dan secara statistik menggunakan one way ANOVA dan uji Tukey dengan taraf kepercayaan 95\%. Hasil penelitian menunjukan bahwa semua formula suppositoria ekstrak daun bayam duri memenuhi persyaratan sifat fisik kecuali $\mathrm{FI}(1 \%)$ yang mempunyai nilai kekerasan $<1,8 \mathrm{~kg}(1,73 \mathrm{~kg})$. Hasil analisis secara statistik menunjukan bahwa penambahan aerosil berpengaruh terhadap kekerasan suppositoria kecuali FI (1\%) dan FII (2\%), penambahan aerosil juga berpengauh pada suhu leleh FI (1\%) dan FIII (2\%), sedangkan pada waktu leleh penambahan aerosil berpengaruh terhadap semua formula.
\end{abstract}

Kata kunci : Bayam duri (Amaranthus spinosus,Linn), Oleum cacao, Aerosil

\section{PENDAHULUAN}

Bayam duri (Amaranthus Spinosus,Linn) merupakan tanaman tradisional indonesia yang mengandung kuersetin (Flavonoid) dan mempunyai fungsi sebagai antiinflamasi pada wasir/hemorroid. Penggunaan bayam duri sebagai antihemorroid di masyarakat dengan cara merebus daun bayam duri kemudian air rebusan tersebut dicucikan pada anus, hal tersebut kurang efektif dalam penyiapan maupun penggunaan. Untuk mengatasi hal tersebut maka ekstrak daun bayam duri dibuat dalam bentuk sediaan yang cocok yaitu suppositoria dengan basis berlemak 
(Oleum cacao). Faktor yang paling menentukan dalam pembuatan suppositoria adalah pemilihan basis, oleum cacao merupakan basis yang mempunyai beberapa sifat yang memenuhi syarat sebagai basis suppositoria seperti, dapat meleleh dalam suhu tubuh dan stabil. Tapi disamping kelebihan tersebut ternyata oleum cacao juga mempunyai kekurangan yang dapat mempengaruhi sifat fisik suppositoria, beberapa penelitian menyebutkan bahwa oleum cacao sukar bercampur dengan ekstrak dan mempunyai viskositas yang rendah sehingga dapat terjadi sedimentasi partikel yang tersuspensi dalam proses pembuatan dan pencetakan (Raymond et al., 2006). Untuk mengatasi hal tersebut, dapat dilakukan penambahan suatu bahan atau zat yang dapat meningkatkan viskositas dan berfungsi sebagai pendispersi yang baik sehingga dihasilkan suppositoria yang memenuhi standar dalam sifat fisik. Aerosil adalah suatu zat yang dapat meningkatkan viskositas dan sebagai pendispersi dalam sediaan suppositoria (Raymond et al.,2006) dengan konsentrasi 2\% - 5\% (Voigt, 1984). Oleh karena itu, penelitian ini bertujuan untuk melihat pengaruh penambahan aerosil dengan konsentrasi yang berbeda - beda (variasi) terhadap sifat fisik ekstrak daun bayam duri yang dihasilkan.

Aerosil merupakan serbuk yang sangat longgar, bercahaya kebiruan, rontgen amorf berwarna putih, terdispersi tinggi, mampu menyerap air sampai $40 \%$ berat, tanpa kehilangan sifatnya sebagai serbuk yang mengalir bebas (Voigt, 1984). Aerosil adalah silikon dioksida murni secara agregat amorf nano ukuran partikel utama memberikan efek sifat alir yang baik pada bahan yang berbentuk serbuk. Ini memberikan efek kekentalan dan thixotropy dengan dispersing pada bahan cair (Semenov et al., 2002). Fungsi aerosil dalam formulasi dan teknologi farmasi adalah sebagai penstabil emulsi, bahan thixotropic dan suspending agent dalam sediaan semi padat. Dalam sediaan tablet aerosil juga digunakan sebagai bahan disintegrant, sedangkan dalam formulasi suppositoria aerosil digunakan untuk meningkatkan viscositas, mencegah sedimentasi pada saat pencetakan serta menurunkan kecepatan pelepasan obat (Raymond et al., 2006).

\section{METODOLOGI}

\section{A. Alat}

Pada penelitian ini alat yang digunakan adalah alat-alat gelas, alat cetak supositoria, alat uji waktu leleh (Erweka jenis SSP), alat uji titik lebur (pipa "U" dengan diameter 0.8 $\mathrm{cm}$ ), alat uji kekerasan, lemari pendingin (Toshiba), stop watch, penangas air (Memert), timbangan analitik (Mettler Toledo Dragon 04), fase diam cellulosa, seperangkat alat sokhlet, rotary evaporator (Heidolph tipe Heizbad WB), Viscometer (Brookfield viscometer DV - 1 Prime), bejana, heating mantle (Gopal), magnetic stirrer (Heidolph 
laborota 4000), moisture balance (Mettler Toledo seri HB 43 Halogen), TLC scanner (Camag TLC scanner 3).

\section{B. Bahan}

Pada penelitian ini bahan-bahan yang digunakan adalah daun bayam duri (diperoleh dari desa Purwosari, Sindudadi, Mlati, Sleman Yogyakarta), aquadest (kualitas farmasetis), oleum cacao (kualitas farmasetis), Aerosil (kualitas farmasetis), paraffin cair (kualitas farmasetis), etanol, kloroform : methanol : asam asetat 10\% (90 : $10: 0,1)$ (kualitas farmasetis).

\section{Prosedur Kerja}

Determinasi tanaman bayam duri (Amaranthus spinosus, Linn)
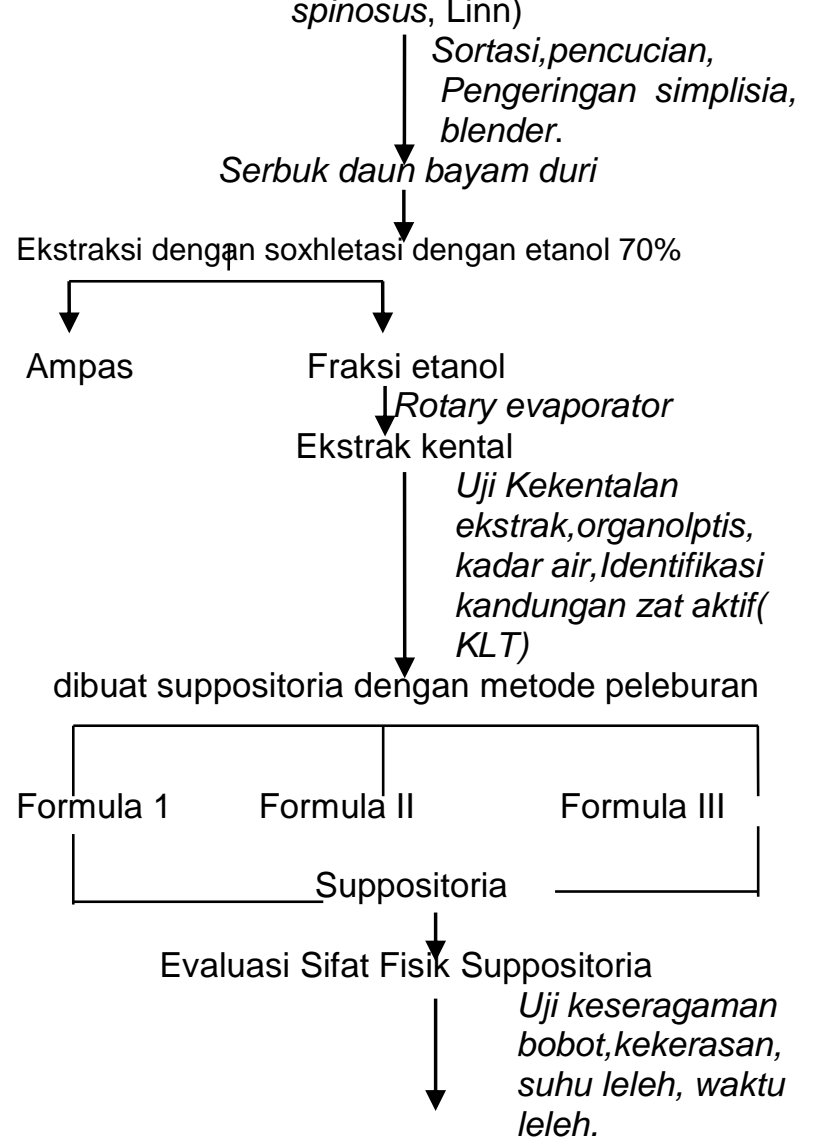

Analisis hasil
Tabel I. Formula Suppositoria Ekstrak Daun Bayam Duri dengan variasi penambahan Aerosil

\begin{tabular}{cccc}
\hline Bahan & $\begin{array}{c}\text { Formula } \\
\text { I }\end{array}$ & $\begin{array}{c}\text { Formula } \\
\text { II }\end{array}$ & $\begin{array}{c}\text { Formula } \\
\text { III }\end{array}$ \\
\hline Ekstrak & $0,35 \mathrm{~g}$ & $0,35 \mathrm{~g}$ & $0,35 \mathrm{~g}$ \\
O.Cacao & $2.63 \mathrm{~g}$ & $2,61 \mathrm{~g}$ & $2,58 \mathrm{~g}$ \\
Aerosil & $0,03 \mathrm{~g}$ & $0,05 \mathrm{~g}$ & $0,08 \mathrm{~g}$ \\
\hline Keterangan : & & & \\
Formula I & : Penambahan Aerosil 1 \% \\
Formula II & : Penambahan Aerosil 2\% \\
Formula III & : Penambahan Aerosil 3\%
\end{tabular}

\section{HASIL DAN PEMBAHASAN}

\section{A. Determinasi Tanaman}

Identifikasi ini dilakukan dengan mengamati dan mencocokan ciri - ciri morfologi dari tanaman menggunakan buku Flora of Java (Backer and Van Den Brink, 1968), sebagai acuan dalam menentukan kunci determinasi. Hasil determinasi yaitu :

$4 b-2 b-3 b-4 b-5 a-6 b-7 b-8 b-9 b-10 b-11 b-12 b-$

13b-14a-15a (golongan 8)-109b-119b-120b128b-129b-135b-136b-139b-140b-142b143b-146a-147a-148b-149a (Amaranthaceae) 1b-4a Amaranthus spinosus $\mathrm{L}$.

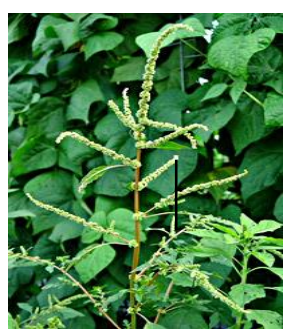

Gambar I. Amaranthus spinosus, Linn (Anonim, 2005).

\section{B. Pemeriksaan Kualitas Ekstrak Daun Bayam Duri}


Ekstrak daun bayam duri yang merupakan zat aktif dalam pembuatan suppositoria kemudian dilakukan uji untuk memastikan kualitas ekstrak yang digunakan bagus. Beberapa uji yang dilakukan meliputi uji organoleptis yang bertujuan untuk mengetahui bentuk, warna, bau dari ekstrak daun bayam duri yang telah dihasilkan, kekentalan, dan kadar air. Berikut hasil uji ekstrak daun bayam duri:

Tabel II. Hasil uji ekstrak daun bayam duri

\begin{tabular}{clc}
\hline No & Jenis Pemeriksaan & Hasil \\
\hline 1 & Organoleptis & \\
& a. Warna & Hijau tua \\
& b. Bau & Khas \\
& c. Rasa & Pahit \\
& d. Bentuk & Cairan Kental \\
2 & Kadar air & $16,8 \%$ \\
3 & Kekentalan & $2962,6 \mathrm{cp}$ \\
\hline
\end{tabular}

\section{Uji Kandungan Kuersetin dengan KLT Densitometri}
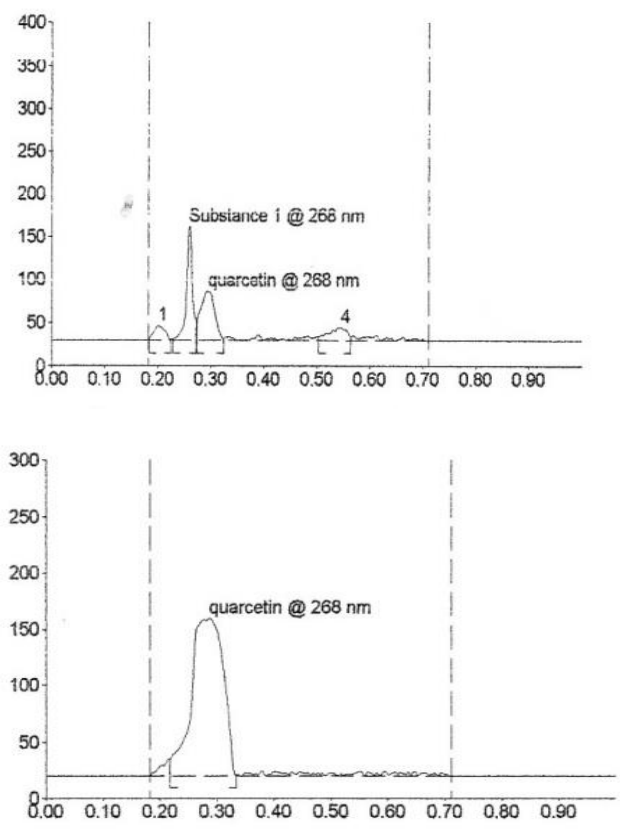

Gambar II. Grafik Harga Rf standar kuersetin (a) dan sampel ekstrak bayam duri (b).

Dari hasil evaluasi densitometri TLC chromatogram dapat dilihat bahwa standar kuersetin dan ekstrak daun bayam duri mempunyai harga retardation factor $(\mathrm{Rf})$ yang hampir sama yaitu harga $\mathrm{Rf}$ standar kuersetin 0,29 dan harga Rf ekstrak daun bayam duri 0,30. Dilihat dari harga $R f$ menunjukkan bahwa ekstrak daun bayam duri positif memiliki kandungan kuersetin. Selain uji kandungan, ekstrak daun bayam duri juga di lakukan uji kuantitatif yang bertujuan untuk mengetahui seberapa besar kandungan kuersetin sebagai zat aktif yang terdapat dalam ekstrak tersebut. Hasil uji kuantitatif tersebut menunjukan bahwa kadar kuersetin dalam ekstrak etanol daun bayam duri adalah $0,17 \%$.

\section{Sifat Fisik Suppositoria}

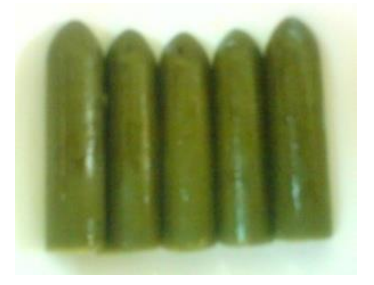

Formula I

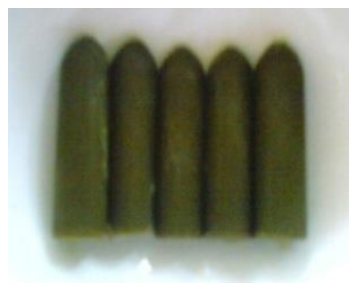

Formula II

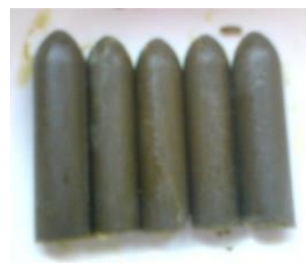

Formula III

Gambar III. Suppositoria ekstrak daun bayam duri

Secara organoleptis suppositoria yang dihasilkan berbeda dalam warna dan homogenitas. Dari ketiga formula diatas, formula III menunjukan hasil suppositoria yang baik jika dilihat secara visual (warna hijau tua merata yang menunjukan 
homogenitas suppositoria) hal ini dapat disebabkan karena suppositoria formula III mempunyai konsentrasi aerosil yang lebih besar (3\%). Aerosil yang berfungsi sebagai pendispersi mempunyai sifat lipofil (-Si) dan hidrofil (-Ho), sehingga jika konsentrasi aerosil tinggi maka kemampuan untuk mengikat molekul air (ekstrak) dan molekul yang mengandung lemak (Oleum cacao) makin besar dan menyebabkan penurunan tegangan antarmuka keduanya, sehingga ekstrak dan oleun cacao dapat bercampur sempurna.

Selain itu perubahan warna pada suppositoria juga dapat disebabkan karena adanya reaksi yang terjadi dari penambahan aerosil itu sendiri karena dari sifat kimianya aerosil mampu berinteraksi ataupun berikatan antar molekulnya sendiri dan aerosil mempunyai (-Si) yang sangat aktif mengikat senyawa lain. Hal ini dapat dinilai dari ketercampuran ekstrak dengan basis pada saat dicampurkan dan homogenitas setelah pencetakan. Dilihat dari sifat aerosil tersebut maka selain mempengaruhi homogenitas pada saat mencampurkan ekstrak dan oleum cacao juga dapat mempengaruhi sifat fisik suppositoria yang lainya, sehingga setelah dicetak masing-masing suppositoria harus melewati beberapa uji fisik seperti keseragaman bobot, kekerasan, suhu leleh dan waktu leleh.
Tabel III. Hasil uji sifat fisik suppositoria ekstrak daun bayam duri dengan variasi penambahan konsentrasi aerosol

\begin{tabular}{lccc} 
Sifat Fisik & $\begin{array}{c}\text { Formula } \\
\text { I }\end{array}$ & $\begin{array}{c}\text { Formula } \\
\text { II }\end{array}$ & $\begin{array}{c}\text { Formula } \\
\text { III }\end{array}$ \\
\hline Bobot $(\mathrm{g})$ & $3,01 \pm 0,0$ & $3,01 \pm 0,0$ & $3,00 \pm 0,0$ \\
& 2 & 2 & 0 \\
Kekerasa & $1,73 \pm 0,1$ & $1,8 \pm$ & $2,00 \pm$ \\
n $(\mathrm{kg})$ & 0 & 0,12 & 0,00 \\
Titik leleh & $32,5 \pm 0,5$ & $33,33 \pm 0$, & $34,66 \pm 1$ \\
$\left({ }^{\circ} \mathrm{C}\right)$ & 5 & 52 & 36 \\
Waktu & $3,37 \pm 0,0$ & $5,25 \pm 0,2$ & $5,99 \pm 0,3$ \\
leleh & 9 & 4 & 7 \\
(menit) & & & \\
\hline
\end{tabular}

a. Keseragaman Bobot

Hasil uji bobot rata - rata suppositoria ekstrak daun bayam duri formula I 3,01 gram CV $0,66 \%$, formula II 3,01 gram CV 0,66\%, dan formula III adalah 3,00 gram dengan CV $0 \%$. Dari data tersebut menunjukan bahwa bobot suppositoria yang dihasilkan memenuhi syarat keseragaman bobot menurut farmakope dimana tidak ada dua suppositoria yang masing-masing bobotnya menyimpang lebih dari $5 \%$ dan tidak satupun suppositoria yang bobotnya menyimpang lebih dari $10 \%$ dari bobot rata - rata suppositoria (Anonim, 1995).

Hasil perbandingan uji keseragaman bobot suppositoria ekstrak daun bayam duri dengan variasi penambahan aerosil dapat dilihat dalam grafik berikut : 


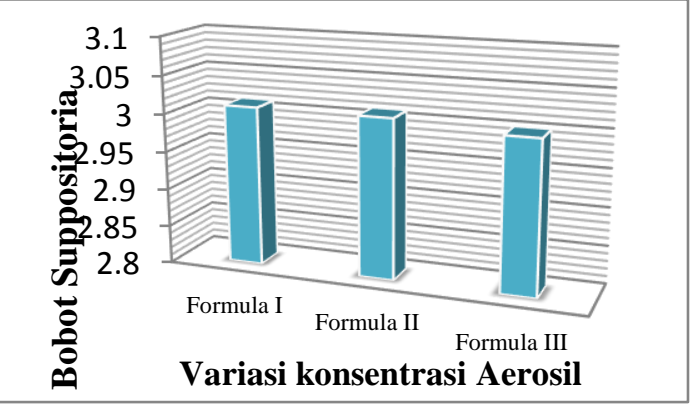

Gambar IV. Hubungan keseragaman bobot dengan variasi penambahan konsentrasi aerosil pada suppositoria.

Hasil analisis statistik dengan metode one way ANOVA dengan taraf kepercayaan $95 \%$ menunjukan nilai probabilitas > 0,05 yaitu 0,314. Hal ini menunjukan bahwa Ho diterima dan berarti bahwa tidak ada perbedaan yang bermakna antara rata-rata bobot suppositoria pada masing - masing formula, sehingga tidak perlu dilakukan uji Tukey. Dapat disimpulkan bahwa variasi konsentrasi aerosil dari ketiga formula mempunyai pengaruh yang sama terhadap bobot suppositoria.

b. Kekerasan suppositoria

Dari uji kekerasan suppositoria ekstrak daun bayam duri pada formula I menghasilkan nilai rata-rata kekerasan 1,73 $\mathrm{kg}$, formula II 1,8 kg, dan formula III 2,0 kg. Suppositoria yang dihasilkan memenuhi persyaratan kekerasan yaitu 1,8 - 2,0 kg (Lieberman et al., 1996). Dari ketiga formula menunjukan bahwa makin besar konsentrasi aerosil yang ditambahkan maka makin keras suppositoria yang dihasilkan, hal ini dikarenakan aerosil yang berfungsi sebagai pendispersi mempunyai dua sifat yaitu lipofil (suka minyak) dan hidrofil (suka air). Gugus lipofil akan mengikat oleum cacao sebagai basis dengan ikatan van der walls dan bagian hidrofilnya akan mengikat air dari ekstrak daun bayam duri dengan ikatan hidrogen, jika semakin banyak konsentrasi aerosil yang ditambahkan maka ikatan-ikatan antar partikel tersebut semakin banyak dan makin kompak sehingga viskositas juga meningkat dan membuat formula menjadi lebih keras, sehingga membutuhkan beban yang besar juga untuk mematahkan suppositoria. Jika kekerasan suppositoria terlalu rendah atau dibawah $1,8 \mathrm{~kg}$ maka dikhawatirkan dapat menyebabkan kerusakan atau menghasilkan stabilitas sifat fisik yang kurang baik.

Hubungan penambahan konsentrasi aerosil terhadap kekerasan suppositoria seperti disajikan dalam gambar berikut :

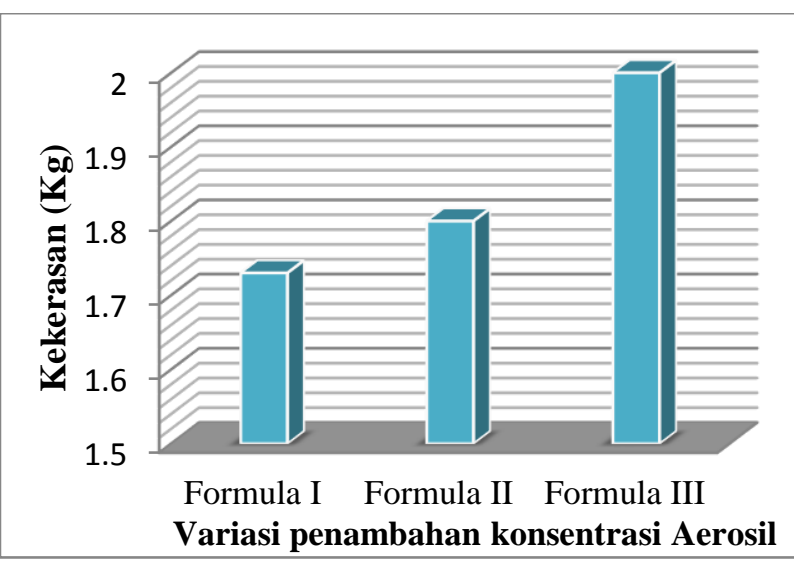

Keterangan :

Formula I : Penambahan Aerosil 1\%

Formula II : : Penambahan Aerosil 2\%

Formula III : Penambahan Aerosil 3\%

Gambar V. Hubungan kekerasan dengan variasi penambahan konsentrasi aerosil pada 
Dari hasil uji statistik menggunakan metode one way ANOVA dengan taraf kepercayaan 95\% diperoleh nilai probabilitas $<0,05$ yaitu 0,01 . Dilihat dari nilai probabilitas maka Ho ditolak sehingga dilanjutkan dengan uji Tukey dengan taraf kepercayaan 95\% untuk mengetahui adanya perbedaan yang bermakna antar formula terhadap kekerasan suppositoria. Berikut disajikan tabel hasil uji Tukey yang menunjukan adanya perbedaan bermakna antar formula :

Tabel IV. Signifikan antar formula terhadap kekerasan suppositoria

\begin{tabular}{cccc}
\hline Formula & I & II & III \\
\hline I & & - & + \\
II & - & & + \\
III & + & + & \\
\hline Keterangan & &
\end{tabular}

Keterangan :
$(+)$
$(-)$
: Berbeda bermakna
: Berbeda tidak bermakna

Dari hasil uji Tukey menunjukan bahwa formula II berbeda tidak bermakna dengan formula I dan formula II, sedangkan formula I dan III menunjukan adanya perbedaan yang bermakna. Hal ini menunjukan bahwa makin besar konsentrasi aerosil yang ditambahkan maka suhu yang dibutuhkan suppositoria untuk meleleh juga semakin tinggi.

c. Suhu Leleh

Dari uji ini dihasilkan suhu yang dibutuhkan untuk suppositoria meleleh pada masing - masing suppositoria yaitu formula I $32,5^{\circ} \mathrm{C}$, formula II $33,33^{\circ} \mathrm{C}$, dan formula III $34,66^{\circ} \mathrm{C}$. Hal ini menunjukan bahwa aerosil dapat mempengaruhi suhu leleh suppositoria, karena aerosil sebagai pendispersi mempunyai sifat lipofil dan hidrofil yang akan mengikat partikel - partikel yang ada pada oleum cacao dan ekstrak. Makin banyak konsentrasi aerosil yang ditambahkan maka makin banyak mengikat partikel, jika ikatanikatan tersebut bertambah banyak dan menjadi kuat maka butuh energi (panas) yang lebih tinggi untuk melepaskan ikatan-ikatan tesebut atau melelehkanya. Dari data hasil uji tersebut menunjukan bahwa suppositoria ekstrak daun bayam duri masuk dalam persyaratan suhu leleh, dimana suhu leleh yang dipersyaratkan yaitu tidak lebih dari $37^{\circ} \mathrm{C}$ (Lieberman et al., 1996). Makin tinggi konsentrasi aerosil yang ditambahkan maka makin tinggi suhu yang dibutuhkan untuk suppositoria meleleh dan makin rendah konsentrasi aerosil maka suhu yang dibutuhkan untuk melelehkan suppositoria makin rendah. Hubungan penambahan konsentrasi aerosil terhadap suhu leleh suppositoria seperti disajikan dalam gambar berikut :

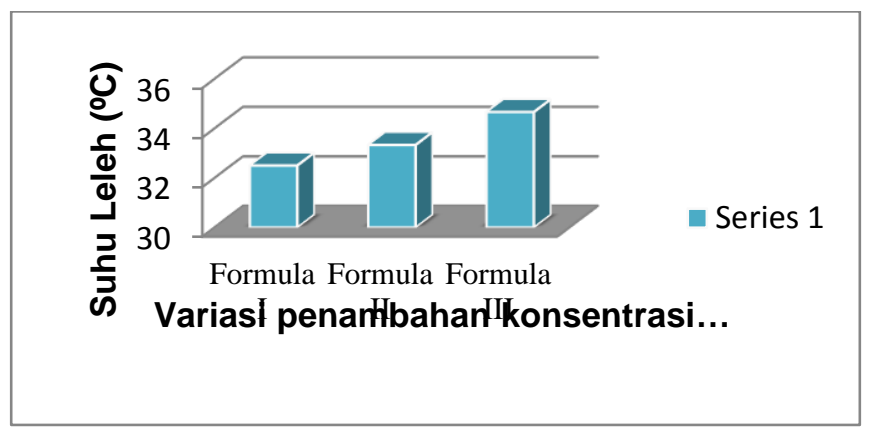

Keterangan :

Formula I : Penambahan Aerosil 1\%

Formula II : Penambahan Aerosil 2\%

Formula III : Penambahan Aerosil 3\% 
Gambar VI. Hubungan suhu leleh dengan variasi penambahan konsentrasi aerosil pada suppositoria.

Hasil uji statistik menggunakan metode one way ANOVA diperoleh probabilitas $<0,05$ yaitu 0,03 sehingga Ho ditolak dan dilanjutkan dengan uji Tukey untuk mengetahui adanya perbedaan suhu leleh yang bermakna antar formula. Berikut disajikan tabel hasil uji Tukey yang menunjukan adanya perbedaan bermakna antar formula :

Tabel V. Signifikan antar formula terhadap suhu leleh Suppositoria

\begin{tabular}{cccc}
\hline Formula & I & II & III \\
\hline I & & - & + \\
II & - & & - \\
III & + & - & \\
\hline
\end{tabular}

Keterangan :

(+) : Berbeda bermakna

$(-) \quad$ : Berbeda tidak bermakna

Dari hasil uji Tukey menunjukan bahwa formula II berbeda tidak bermakna dengan formula I dan formula II, sedangkan formula I dan III menunjukan adanya perbedaan yang bermakna. Hal ini menunjukan bahwa makin besar konsentrasi aerosil yang ditambahkan maka suhu yang dibutuhkan suppositoria untuk meleleh juga semakin tinggi.

d. Waktu Leleh

Uji yang dilakukan pada suppositoria ekstrak daun bayam duri menghasilkan waktu leleh pada F I 3,37 menit, F II 5,25 menit, dan F III 5,99 menit. Hal ini menunjukan bahwa waktu yang dibutuhkan suppositoria ekstrak daun bayam duri untuk meleleh masuk dalam syarat waktu leleh yang ditentukan yaitu kurang dari 30 menit (Lieberman et all., 1996). Dari hasil uji ini menunjukan bahwa F I merupakan suppositoria yang memiliki nilai nilai sifat fisik yang paling rendah sedangkan F III mempunyai waktu leleh yang paling lama (5,99 menit), tingkat kekerasan $(2,00 \mathrm{~kg})$ dan suhu lebur $\left(34,6^{\circ} \mathrm{C}\right)$. Hal ini dapat disebabkan karena dari sifat aerosil sebagai zat pendispersi yang dapat mengikat bagian hidrofil dan lipofil dari campuran ekstrak dengan oleum cacao, konsentrasi yang lebih besar akan membentuk ikatan antar partikel yang lebih banyak dan kompak, sehingga butuh beban $(\mathrm{kg})$ dan tenaga $\left({ }^{\circ} \mathrm{C}\right)$ yang cukup besar, serta waktu (menit) yang cukup lama untuk melepaskan ikatan - ikatan tersebut. Dari hasil uji yang dilakukan dalam penelitian ini menunjukan bahwa makin banyak konsentrasi aerosil yang ditambahkan maka makin meningkat pula nilai-nilai sifat fisik dari suppositoria ekstrak daun bayam duri tersebut. Hubungan penambahan konsentrasi aerosil terhadap kekerasan suppositoria seperti disajikan dalam gambar berikut :

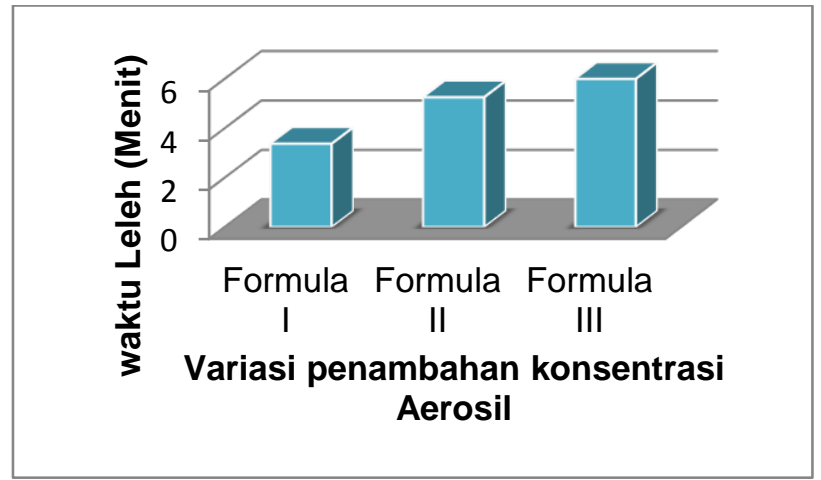

Keterangan :

Formula I : : Penambahan Aerosil 1\% 
Formula II : Penambahan Aerosil 2\%

Formula III : Penambahan Aerosil 3\%

Gambar VII. Hubungan waktu leleh dengan variasi penambahan konsentrasi aerosil pada suppositoria

Uji statistik menggunakan one way

ANOVA diperoleh nilai probabilitas $<0,05$ yaitu 0,043. Dari nilai probabilitas tersebut maka perlu dilakukan uji Tukey dengan taraf kepercayaan 95\% untuk melihat adanya perbedaan waktu leleh yang signifikan terhadap tiap formula. Berikut disajikan tabel hasil uji Tukey yang menunjukan adanya perbedaan bermakna antar formula :

Tabel VI. Signifikan antar formula terhadap waktu leleh suppositoria

\begin{tabular}{cccc}
\hline Formula & I & II & III \\
I & & + & + \\
II & + & & + \\
III & + & + & \\
\hline
\end{tabular}

Keterangan :

(+) : Berbeda bermakna

(--) : : Berbeda tidak bermakna

Di lihat dari hasil tersebut dapat disimpulkan bahwa perbedaan konsentrasi aerosil yang ditambahkan untuk tiap formula memberikan pengaruh yang berbeda secara bermakna terhadap waktu leleh suppositoria, makin besar konsentrasi penambahan aerosil maka makin lama waktu yang dibutuhkan suppositoria untuk meleleh.

\section{KESIMPULAN}

1. Semua formula suppositoria ekstrak daun bayam duri dengan penambahan Aerosil 1\% (FI), 2\% (FII), 3\% (FIII) memenuhi persyaratan sifat fisik (kekerasan, suhu leleh, dan waktu leleh) kecuali FI yang mempunyai nilai kekerasan $<1,8 \mathrm{~kg}(1,73$ $\mathrm{kg})$.

2. Penambahan variasi konsentrasi aerosil berpengaruh terhadap kekerasan suppositoria kecuali FI dan FII, penambahan variasi konsentrasi aerosil juga berpengauh pada suhu leleh FI dan FIII, sedangkan pada waktu leleh penambahan aerosil berpengaruh terhadap semua formula.

\section{DAFTAR PUSTAKA}

1. Anonim, 1995, Farmakope Indonesia,edisi IV, Departemen Kesehatan Republik Indonesia, Jakarta, 404.

2. Becker, C. A., \& Van den Brink, R. C. B., 1968, Flora of Java (Spermatophytes only) vol II, Groningan-The Netherlands, Wolters-Noordhoff. N. V

3. Lieberman, H.A., Rieger, M.M., and Banker, G.S., 1996, Pharmaceutical Dosage Form, Disspers System, in three volume, Vol.2, Marcel Dekker.Inc, New York, 473.

4. Pristianty, L., Ekarina, H., dan Rosita, N., 2004, Uji Karakteristik Fisis dan Pelepasan Diklofenak Dietilamonium dari Berbagai Basis Suppositoria, Majalah Farmasi Airlangga, Vol. 4, No. 1, 6-12 (diakses 01 Desember 2008).

5. Raymond, C.R., Paul, J.S., and Siân, C.O., 2006, Pharmaceutical Excipients, Pharmaceutical Press and the American Pharmacists Association, America, 127.

6. Semenov, A.D., Golikova, E.V., Grigor'ev, V.S., Kulagin K.M., 2002, Structurization of Aerosil OX50 Dispersions, Russian Journal of General Chemistry, Volume 72, 
Pengaruh Penambahan Aerosil Terhadap Sifat Fisik Suppositoria Ekstrak Daun Bayam Duri (Amaranthus Spinosus, Linn) Dengan Basis Berlemak (Oleum Cacao)

Number 1, pp. 17-25(9) (diakses 01

Desember 2008).

7. Sudjadi, 2007, Kimia Farmasi Analisis.Pustaka pelajar, Yogyakarta, 98 111.

8. Voigt, R., 1984, Buku Pelajaran Teknologi Farmasi, Edisi V, diterjemahkan oleh Soendani N.S., Mathilda, B.W., Gadjah Mada University Press, Yogyakarta, 282306. 